\title{
The Migratory Process and the Volleyball Ranking: First Approaches
}

\author{
Rafael Marques Garcia, Diego Ramos Do Nascimento, Erik Giuseppe Barbosa Pereira
}

Games Department, Federal University of Rio De Janeiro, Rio De Janeiro, Brazil

Email address:

rafa.mgarcia@hotmail.com (R. M. Garcia), personalnascimento@gmail.com (D. R. Nascimento), egiuseppe@eefd.ufrj.br (E. G. B. Pereira)

\section{To cite this article:}

Rafael Marques Garcia, Diego Ramos Do Nascimento, Erik Giuseppe Barbosa Pereira. The Migratory Process and the Volleyball Ranking: First Approaches. American Journal of Sports Science. Vol. 5, No. 4, 2017, pp. 21-26. doi: 10.11648/j.ajss.20170504.11

Received: August 18, 2017; Accepted: September 4, 2017; Published: September 22, 2017

\begin{abstract}
The migratory phenomenon can also be seen in volleyball nets. Initially, this sport's movement, immediately, triggered the implementation of managerial mechanisms in this process, such as the Official Athlete Ranking. The objective of this study was to analyze, throughout history, the influence of the ranking mechanism in the migration process of athletes in Brazilian's volleyball, in order to answer the following question: how has the ranking policy been interfering in this process? This study is qualitative in nature, using discourse analysis as a strategy. With regard to the instruments, a semi-structured interview was used, containing 1 script with 8 questions about the subject. The sample counted with 10 interviewees, being 2 technicians and 8 athletes of the teams that won the Super League's titles at that time. The CBV imposes measures to preserve the internal market and, beyond this imposition, it's possible to observe that the market attached to the financial valuation and the cultural and social aspects are influential factors in the movement of the athletes.
\end{abstract}

Keywords: History, Migration, Volleyball, Ranking

\section{Introduction}

By your notoriety, migration is commonly appreciated in soccer, where high salaries paid abroad, greater media visibility and greater prestige among fans/consumers attract players in general [1].

A few years ago, Brazil ceased to be a receiving country for immigrants to become a country that provides migrants to the world [2]. This migratory flow is present with intensity also in sports. The emigration of soccer players is accompanied by sports development over the decades, especially in relation to economic and social factors [2].

With the growing movement of foreign athletes, restrictions were imposed legally and professionally over Brazilian athletes abroad. In soccer in 1970, there was a limitation on the number of non-naturalized players per club abroad and the abdication of the Brazilian national team by those who ventured into foreign lands [3]. Already in athletics, it's possible to see that this limitation is also present on the foreign corridors that compete in Brazil [4].

The migratory phenomenon can also be seen in volleyball nets. The process of professionalization in Brazil occurred between 1980 and 1990 with the persistence of Nuzman, the president of "Confederação Brasileira de Voleibol" (CBV) that time. Your innovative proposal to associate companies, clubs, athletes and the media, allowed the companies to sponsor the clubs and the Brazilian teams, which were standing out internationally [5]. In this scenario, the Brazilian's volleyball had a qualitative leap in level and competitions and a lot of talented players appeared. The author already emphasized this sport as one of the most practiced in Brazil, due to the aforementioned factors, which strengthened the national competitions and reinforces the current position of the masculine (1st) and feminine (3rd) adult teams of Brazil.

The decade of the 90 was marked by the migration of many athletes to foreign countries, a fact due to the crisis that was happening in Brazil, where players of various modalities emigrated, not being different in volleyball, which lost great names to European and Japanese clubs. This sport's movement, immediately, triggered the implementation of managerial mechanisms in this process.

Since the 16th edition of Brazilian Super League (20092010), the championship has been marked by the return of 
many Brazilians due to the organization and high level. The season counted with the repatriation of 43 athletes and the record of participating teams: 30 [6]. Such ordinations, however, may have been modeled by the global financial crisis of 2008/2009, where Brazil showed a reasonable contrast to the global condition in this period.

Nowadays, the international achievements of the Brazilian national teams have secured this imposition on the courts, especially after the two conquers of Women's Olympic gold medal and the Men's second places at the 2008 and 2012 Olympic Games. Another factor to consider is the constant renewal of the selections, which keeps their high level.

After the above, the objective of this study was to analyze initially, throughout history, the influence of the ranking mechanism in the migration process of athletes in Brazilian's volleyball, in order to answer the following question: how has the ranking policy been interfering in this process?

\section{Methodology}

This study is qualitative in nature, seeking to spread the possibilities of analyzing and perceiving social phenomena, rather than closing or concluding them [7]. It was used the discourse analysis as a strategy[8, 9]. With regard to the instruments, a semi-structured interview was used, containing 1 script with 8 questions about the subject.

The intentional sample counted with 10 interviewees, being 2 coaches - Bernardinho (BE) and Marcelo Fronckowiak (MF) -, and 8 athletes: Bruninho (BR), Leandro Vissoto (LV), Riad (RI), Vini (VN), Fofão (FF), Fabi (FB), BrankicaMihajlovic (BM) and Sarah Pavan (SP).

In order to facilitate the understanding of the results, the speeches were filteredin sections that involved the study object. All of the interviewees experienced migratory processes, that is, they had the experience of emigrating between Brazilian's cities, such as well they had the experience of also playing for a foreign club (except the libero FB). It should be noted that all the interviewees, except $\mathrm{BM}$ and SP, gave their answers in Portuguese, then, for a better understanding, their speeches are here translated into English.

\section{Analysis and Discussion}

The Official Athlete Ranking (OAR) was implemented in Brazil on the 1992/1993 edition, under the justification of elaborating regulatory mechanisms according to the technical level of athletes of the Super League teams. The adoption of this strategy has brought consequences to the labor market and imposed limits on the circulation of players in these teams.

When asked about this ranking policy, BE says:

$\mathrm{BE}$ : The ranking is already, so to speak, adapting to the issue of player migration and is not so favorable at times because they will count points for teams, so can, with foreigners also very good, you can burst the point limit.

In contrast to the high concentration of highly qualified athletes in one or two teams, he complements:

BE: It is a way for you to try to make these great players distribute themselves a little and not to be all concentrated on one team.

MF complements:

MF: The capitalist system introduces some tools of control, but not of total control as it is done through the ranking [...] the ranking hinders free circulation.

Among the athletes, FF reveals the aggravating imposition of the ranking:

FF: The seven-point player has at least one salary ceiling and often does not have a team that can sometimes pay for it, so the player sometimes prefers to leave the country, he prefers to look for other things outside the country than to play in an average team, a team that does not have much objective in a championship.

FB has the same line of reasoning, but believes that the ranking is not responsible for this exodus:

FB: Today there is place for everyone, the ranking today gives space to all players. Maybe the only problem is this, you want to play on a team and have no points or space for you. Then you will be forced to suddenly live in another city, having to adapt to another training style of another coach, but I do not see the ranking as the main responsible for the exit of the athletes from the country today.

For the Serbian athlete $\mathrm{MH}$, the impositions of the ranking regarding the presence of foreigners are valid:

MH: I think in one way, it's good that some teams and some competitions or some countries, you have limited number of foreign players. We are coming and I think it's also a good idea to protect the players who are playing for the nation. So I think they are trying to make a balance between this.

MF, however, emphasizes another side derived from ranking:

MF: The idea of ranking is to make Brazilian players stay in Brazil, it is to value the training clubs.

This perspective of valorization of training clubs is, in fact, described in the OAR, which qualifies with a score of 0 the athletes registered by the same team from a certain category. However, this mechanism presents exceptions that favor the emergence of the dynasty of clubs, such as the maintenance of a certain cast, the encouragement of CBV to the repatriation of Brazilian athletes, the enforcement of previous regulations under the current regulations regarding the hiring of foreigners - the Cuban Leal, currently in the SADA/Cruzeiro, continues with the score of 0 since his hiring, because that time the regulation determined that any foreign contractor would not add points to the team. At present, any foreigner who is hired will have 5 points and each team has the right to enroll a maximum of two athletes of foreign nationality - and the age bonus - after the age of 36 , every year more decreases one point of the athlete.

When attempting to the last ten editions of the Super League, it's possible to notice that the same teams have 
played the respective finals again and again:

Table 1. Results of the last 10 editions of the Super League.

\begin{tabular}{|c|c|c|c|}
\hline Season & Gender & Champion & Runner-up \\
\hline \multirow{2}{*}{$2007 / 2008$} & $\mathrm{M}$ & CIMED & TCM/Minas \\
\hline & $\mathrm{F}$ & Rexona-Ades & Finasa/Osasco \\
\hline \multirow{2}{*}{$2008 / 2009$} & M & CIMED & Vivo/Minas \\
\hline & $\mathrm{F}$ & Rexona-Ades & Finasa/Osasco \\
\hline \multirow{2}{*}{$2009 / 2010$} & M & CIMED & Montes Claros \\
\hline & $\mathrm{F}$ & Sollys/Osasco & Unilever \\
\hline \multirow{2}{*}{$2010 / 2011$} & M & SESI-SP & SADA/Cruzeiro \\
\hline & $\mathrm{F}$ & Unilever & Sollys/Osasco \\
\hline \multirow{2}{*}{$2011 / 2012$} & M & SADA/Cruzeiro & VôleiFuturo \\
\hline & $\mathrm{F}$ & Sollys/Nestlé & Unilever \\
\hline \multirow{2}{*}{$2012 / 2013$} & M & RJX & SADA/Cruzeiro \\
\hline & $\mathrm{F}$ & Unilever & Sollys/Nestlé \\
\hline \multirow{2}{*}{$2013 / 2014$} & M & SADA/Cruzeiro & SESI-SP \\
\hline & $\mathrm{F}$ & Unilever & SESI-SP \\
\hline \multirow{2}{*}{$2014 / 2015$} & M & SADA/Cruzeiro & SESI-SP \\
\hline & $\mathrm{F}$ & Rexona-Ades & Molico/Nestlé \\
\hline \multirow{2}{*}{$2015 / 2016$} & M & SADA/Cruzeiro & Brasil Kirin Vôlei \\
\hline & $\mathrm{F}$ & Rexona-Ades & Dentil/Praia Clube \\
\hline \multirow{2}{*}{$2016 / 2017$} & M & SADA/Cruzeiro & Funvic/Taubaté \\
\hline & $\mathrm{F}$ & Rexona-Ades & Vôlei Nestlé \\
\hline
\end{tabular}

SOURCE: CBV, 2017 [10]

In the opinion of MF, ranking would be ruled out if Brazilian volleyball were managed in another way:

MF: We would not have the ranking if we had better exposure of brands, if we had more companies, an enjoyable championship, more profitable, more media... This is the big problem of Brazilian volleyball, dude. We do not have enough clubs to absorb the amount of player we produce.

It should be noted that recently, in 2017, a group of athletes from Brazilian team, acting in the Brazilian Super League, expressed their disapproval of the new reformulations promoted in the OAR document. The letter, addressed to $\mathrm{CBV}$, reveals the dissatisfaction with the guidelines imposed by the entity, revealing that not all professionals involved are satisfactorily contemplated in this scenario. To illustrate, the letter follows, translated into English:

\section{Repudiation note of athletes to $C B V$}

We, Danielle Rodrigues Lins, Fabiana Marcelino Claudino, Fernanda Garay Rodrigues, Gabriela Braga Guimarães, Jaqueline Maria Pereira de Carvalho Endres, Natália Zílio Pereira, Sheilla Castro de Paula Blassioli, Tandara Alves Caixeta and Thaisa Daher Pallesi, Brazilian volleyball athletes, affected by the ranking adopted by $C B V$ Confederação Brasileira de Voleibol - repudiate the regulation of the ranking voted on March 14th, 2017, and imposed for the season 2017/2018.

The ranking, which has already been criticized on several occasions, is an anomaly that exists only in Brazil, under the pretext of creating balance in the competition. However, there was never balance, just check the few changes in the Super League winners of recent years to verify it. The problem of Brazilian volleyball is structural and it is impossible to correct it with a ranking that creates an artificial and theoretical balance.
The ranking has always created problems for athletes, especially those with higher scores. The limitations imposed by the regulation don't answer the interests of the athletes, who are the true protagonists of the sporting events. It is still unconstitutional, considering that it imposes restrictions on freedom of work of the athletes, the right of each one to choose as the free market, and forces the reduction of wages, which is inconceivable. It is important to remember, too, and regret, that athletes' opinions have never been heard, even taken into account in the decisions that involve ranking.

The $C B V$ itself created the so-called 'Athletes Commission', but this commission linked to the institution itself has only one vote in the ranking decision. It is unreasonable. If there are about 10 voting clubs, the athletes will never have a chance against the others. We repeat: it is unreasonable. When will the athletes' will prevail? The way things are, never!

The situation will get even worse in the 2017/2018 season, as we know that the new format of the ranking will only score nine athletes, the same nine that are scored with seven points (maximum score) in the current season. Only we will be subjected to restrictions. We cannot be hired freely by the teams, as each team can only have two of this nine, unlike the other athletes who will be freely chosen, which constitutes clear discrimination and disrespect.

If things remain that way, we will be undermined by the fragile and theoretical 'balance of the championship' argument. We, who defend the Brazilian national team, that we stand out, will now be punished for this. It is unreasonable. In fact, there is no logic in this. We want to be treated equally, lest we come to the Judiciary, in view of the clear and manifest affront to constitutional principles.

In addition, foreigners will not be punctuated, which further diminishes the options of the nine Brazilian women discriminated against. It is worth mentioning that on March 14th, 2017, CBV itself announced the 'Super League Selection' and in it there are three foreigners: Destinee Hooker, Alexandra Klineman and Branda Castillo. All three are high level athletes and will be chosen freely by the teams for the next season, instead of the nine Brazilian ones scored. In addition, in this 'Super League Selection' there is only one athlete of the nine present in the ranking. This shows that the ranking system does not have clear criteria and does not fulfill its supposed function.

In view of the above, we demand that $C B V$ take action to extinguish the ranking and stop interfering in the right of choice of each athlete. The athletes need to have a voice independent of the confederation and have equal weight in the voting of the regulation. If on one side the clubs pay the salaries, on the other are the athletes who give the show and attract the audience.

We expect a positioning of $C B V$ in up to 5 (five) days. We are open to discuss this problem in order to solve this [11].

The CBV promptly responded with an official statement stating that the decision was taken by a vote in the presence of representatives of the Athletes Commission, maintaining, finally, the implementation of the system. This note is also 
translated into English:

\section{Official CBV note}

The "Confederação Brasileira de Voleibol" $(\mathrm{CBV})$ has the practice of dividing decisions with its main partners and this was repeated last Tuesday (March, 14th, 2017), in a meeting held in São Paulo (SP), with clubs and representative of the Athletes Commission with the objective of defining parameters and outlining strategies for the 2017/2018 Super League's edition for men and women, and we all decided to keep the ranking in the women's competition with seven of the nine votes in favor, demonstrating that the entity does not take unilateral decisions.

The Super League is a competition managed by the CBV, but the clubs and athletes are the protagonists. Therefore, it was their decision, as well as the dispute system of the 16/17 edition, which determined better series of three games in the women's playoffs, and five in the men's. The ranking was implemented in the season 92/93, with the aim of generating balance between the teams and, in a democratic way, has been maintained by the choice of the participating clubs [11].

So, this initiative did not have the desired repercussion for the collective, since the current regulation of the Brazilian Super League maintained the same rules of the first document released for the 2017/2018 season.

In order to deepen the analysis on Sport's migration, it will be analyzed other aspects linked with the ranking that are determinant in these transactions and were cited by the research subjects themselves. So, the next words deal with the financial aspects involved in this process.

To better understand the essence of this aspect, it's important to attempt the migration is always a multi-causal social situation: the motivation of sports migrants is also complex and multifaceted [12]. Besides, the migration is related to geographic, cultural and economic aspects, the presence of companions of his country and the language [12]. Another reason for this mobility is the possibility of generating relationships between clubs, the exchange of athletes and coaches and the presence of sports agents. It's possible to understand as "pressure factors" the mechanisms imposed by structural conditions that in many cases force and/or encourage athletes to emigrate [13].

In addition to these causes of migration, there are some discrepancies involved in this process, such as: wage disparities, job insecurity in relation to the market capacity to absorb athletes and the social differences between sending and receiving athletes over countries, factors mentioned by the interviewees involved in this research [12].

In the speeches of athletes and coaches, it's possible to note that going through the experience of being trained by internationally recognized coaches is one reason why athletes migrate from their country of origin, because this strategy is associated with a career ascent of each player as well as better financial benefits. BE contributes with this assertion when he says:

BE: Many times a young athlete comes to play in Brazil, which is a League of great level, has great coaches, so athletes have a good experience in Brazil. Many of them mature, grow here. An athlete's career is a relatively short career, so they really want to get, to give the highest income possible to have career benefits.

In agreement with this testimony, the Brazilian national team's coach, BR, highlights:

BR: We have a career, let's say, short. We have to take advantage of the financial opportunities that we have to... when we have a good proposal we go there. And also to play a new challenge, right, a new championship, so I think it's part of it.

This speech is in harmony with the statement of RI, which, when asked what factors influenced its choice, replied:

RI: It was, first of all, the financial side. And second, because of what I said, this championship is one of the strongest in the world and has players of a very high level, Olympics' World Champions.

Although the outward movement of some players has not been driven by money, such as the athlete FF, she points out that the financial question is decisive in this process:

FF: In the old days, when I went to Italy, the wages were really high, the euro was very high, so it was a very worthwhile thing, although I did not leave the country for money, it was by choice, but I believe that what attracts the player to leave his country for sure is the financial part.

About this international migratory process, understood as a phenomenon in the field of Sport, it only assumes the level of globalization when observed three guidelines [14]: first, Sport's migration is not an emerging phenomenon; second, there is growth in all aspects involving international migration in Sports and; third, migration in globalized Sport has contributed to the development of professional and international careers and the acquisition of significant results in their origin country [14].

From this observation, it is confirmed that many athletes come, others go and some still opt to stay on the same team, a fact proven by FB:

FB: I wanted to play here, it was a dream to play in Unilever for me, I live in my house, I'm close to my friends, it's logical that the financial part weighs a lot, but personal satisfaction, being close to my friends on the beach, I think I gave a lot more priority to well-being than just money, but some things for me, they do not have much financial value, it's more a personal satisfaction.

This permanence of the athlete in a same team would also be of great value for the Brazilian clubs, since these would be subsidized with individualized score according to the regulation of the CBV. Therefore, the permanence of athletes formed in the clubs can be interpreted as a personal strategy that meets the interests of the clubs.

It is undeniable, however, that through this professional "exchange" the involved ones acquire certain experience and knowledge in several aspects, like professional, cultural and social, being even defended by some athletes like SP:

SP: I think that to live in another country is an experience that everyone needs to prove. Trying to live in a different culture is not easy, but you learn a lot from the world and it's very important. 
Therefore, we questioned the interviewees about this performance outside the country. BE reveals:

$\mathrm{BE}$ : It was a very enriching experience, in every aspect: to know a different culture, to meet a different type of athlete, to know a very organized and slightly different championship [Italy], then all this for me was certainly an enriching experience in my coaching career.

When asked about a possible to return abroad, he says:

BE: Unilever's support is an incredible thing, we feel like part of a big family, so I'm happy where I am. So it's not something that appeals to me right now.

MF highlights as fundamental the adaptation factor:

MF: When we are willing to do a work of excellence, quality, we have to adapt to the environment.

When asked about his return to Brazil, he said:

MF: I had already been talking to my wife for some time, our youngest son was going to be 6 years old, it would be time to go to basic school, fundamental here in Brazil. My name, professionally, was beginning to be forgotten, others were already emerging, understood? People no longer remembered me much and Minas was a beautiful opportunity in an extremely structured club. And here in Brazil, being faced with a new opportunity influenced my transition from Minas to the RJX team, thus becoming a motivational factor in this process. I'm happy with the proposal, I'm going to direct Lucão, Bruninho and company, understand? So I think the professional challenge is great.

And he also emphasizes that:

MF: There are a lot of people today who would be interested in working with us, the athletes speak "it would be nice to work with you, I would like to work with you, you are a guy who, over the years, shows a quality of legal work".

Analyzing all the discourses, it's possible to note that the cultural aspect and the family relationship are very determinant factors in this process. These indications are even more evident in the speech of MF:

MF: Ten years ago, seven years ago, I would never live in Rio. For all that Rio represented as negative in Brazilian culture. Whenever I made decisions in my professional life, they were linked to my family. Even now, I'm making a decision. I made a decision to reject proposals and not leave because my family is very well. It's very difficult for you every two years to be changing, remaking friends, the circle of friends.

It was also encountered difficulties arising from this migratory journey. LV quotes the distance as one of them and comments about his adaptation process:

LV: We really feel the distance from home, but after a year I was already well adjusted and then I started to live outside [Italy] calmly, so I would return without any problem.

SP emphasizes the importance of having someone around, in this case, his husband:

SP: I'm here with my husband, he lives here with me and I've already played without anyone, alone, and it's very difficult, we have no friends, no family. Everyone who plays here [Brazil], the national ones, they have a life apart from volleyball, but for foreigners it is difficult, because life is here, with volleyball, but living with my husband makes my life much easier now.

The language also presents itself as an obstacle in some cases, such as the case of $\mathrm{VN}$ :

VN: Look, in Argentina it was difficult at first because of the fact that I just spoke, I did not speak Spanish, much less English.

FF adds:

FF: It's never easy, you go to another country, with another language, you know, different cultures. You have to adapt to the country you're going to, you have to respect the rules, how each country works and sometimes it's difficult for us.

She points out that help from third parties is paramount in this process of adaptation:

FF: We can overcome difficulties, we can find people who help us, find a Brazilian who sometimes lives in the country who can also provide assistance.

Finally, it is undeniable that the ranking, coupled with the market, cultural and social values of the present time are primary devices that act in the Sport's migrations in the diverse modalities.

\section{Conclusion}

The study inferred that the migration phenomenon transforms incisively volleyball into a professional field of certain profitability. The $\mathrm{CBV}$ imposes measures to preserve the internal market and, beyond this imposition, it's possible to observe that the market attached to the financial valuation and the cultural and social aspects are influential factors in the movement of the athletes.

In certain way, the coaches say that the ranking, even appropriated to the migratory issues, can cause problems with the overflow of points with foreign players for teams, where there is a possibility of a distribution of high level athletes between them. They add that the ranking has full control power, curbing the free movement of athletes.

Among the athletes, it is revealed that the OAR-based salary cap causes players to seek other markets, because some teams cannot afford them. But the interviewed do not think the ranking is the biggest responsible for this exodus, which reveals a disagreement between the category, inasmuch as only athletes with maximum score believe to be being impaired in this context.

For foreigners, the impositions are valid for the protection of athletes who play for their nation. The valorization in the training team, which qualifies the athletes enrolled in a certain category with a score of 0 , is another argument. However, this mechanism presents exceptions that favor the emergence of the dynasty of clubs, such as the maintenance of a certain cast, the encouragement of CBV to the repatriation of Brazilian athletes, the enforcement of previous regulations under the current regulations regarding the hiring of foreigners and the bonus for age.

Although the ranking fulfills the role of maintainer in the open market for intermediate level players, this mechanism is one of the direct responsible of the migratory flow of the 
Brazilian athletes since its creation, altering the course of Brazilian's volleyball history.

\section{References}

[1] SOARES, A. J. G. et al. Jogadores de Futebol no Brasil: Mercado, Formação de Atletas e Escola. Rev. Bras Ciênc. Esporte, Florianópolis, v. 33, n. 4, p. 905-921, out/dez. 2011. Trimestral.

[2] RIAL, C. Rodar: A Circulação dos Jogadores de Futebol Brasileiros no Exterior. Horizontes Antropológicos, Porto Alegre, v. 30, n. 14, p. 21-65, jul/dez. 2008.

[3] TONINI, M. D. "Ahhh, no estrangeiro, você é sempre estrangeiro": reflexões sobre a e/imigração de futebolistas brasileiros e o racismo no futebol europeu a partir de uma entrevista com o ex-atleta Paulo Sérgio. Esporte e Sociedade, ano $8, \mathrm{n}^{\circ} 21$, mar. 2013.

[4] RIBEIRO, C. et al. Tem um queniano correndo entre nós: atletismo e migração no Brasil. Rev. Bras. Educ. Fís. Esporte, (São Paulo), vo 27, n. 3, p. 401-10, Jul-Set, 2013.

[5] MARCHI JR., W.“Sacando" o voleibol: do amadorismo à espetacularização da modalidade no $\operatorname{Brasil}(1970$ - 2000). 2001. 282 pages. Doctoral thesis, Department of Physical Education, Universidade Estadual de Campinas, Campinas, 2001.

[6] CONFEDERAÇÃO BRASILEIRA DE VOLEIBOL (CBV). História do Voleibol. Available in: $<$ http://www.cbv.com.br/v1/institucional/histvolei.asp >. Acess in: 14 aug. 2015.
[7] DEMO, P. Pesquisa e informação qualitativa: aportes metodológicos. 5th ed. Campinas: Papirus, 2012.

[8] ORLANDI, E. de L. P. A linguagem e seu funcionamento: as formas do discurso. 6th ed. Campinas: Pontes, 2011.

[9] PÊCHEUX, M. O discurso: estrutura ou acontecimento. 5th edição. Tradução Eni Orlandi. Campinas: Pontes, 2014.

[10] [CONFEDERAÇÃO BRASILEIRA DE VOLEIBOL (CBV). História \& Campeões. Available in: $<\mathrm{http} / / /$ superliga.cbv.com.br/historia-campeoes $>$. Acess in: 20 aug. 2017.

[11] GLOBOESPORTE.COM. CBV responde carta de repúdio e se defende de críticas ao ranking: Entidade diz que decisão de manter limite de atletas de sete pontos foi tomada em votação com presença de representante da Comissão de Atletas. Rio de Janeiro, 20/03/2017, 16h17, atualizado 20/03/2017, 16h17. Available in:

$<$ https://globoesporte.globo.com/volei/noticia/cbv-respondecarta-de-repudio-e-se-defende-de-criticas-ao-ranking.ghtml>. Acess in: 30 aug. 2017.

[12] SOCA, D. W. S. Deporte y migración: aportes para su comprensión desde El caso uruguayo. Revista da ALESDE, Curitiba, v. 2, n. 2, p. 33-43, Outubro, 2012.

[13] PUENTES, R.; CANALES, A.; RODRÍGUEZ, H.; DELGADO-WEISE, R.; CASTLES, S. Towards an assessment of migration, development and human rights links: conceptual framework and new strategic indicators. Peoples' Global Action on Migration, Development, and Human Rights IV Global Forum. Ciudad de México, 2010.

[14] BLANCO, C. Las migraciones contemporáneas. Madrid: Editorial Alianza, 2000. 